Section 2

\title{
Digital Realities of Indigenous Language Revitalization: A Look at Hawaiian Language Technology in the Modern World
}

\author{
CANDACE KALEIMAMOOWAHINEKAPU GALLA \\ University of British Columbia
}

\begin{abstract}
This paper discusses some barriers, complexities, and opportunities Indigenous peoples face when engaging in language revitalization efforts, and how those elements contribute to the adoption, adaptation, or abandonment of digital technology. I begin with framing the context of Indigenous languages in the United States and Canada to underscore the current realities in comparison to world languages. The next section introduces the uptake of digital technology for Indigenous language learning, based on the themes of equity, access, and engagement. I conclude with a case study of the Hawaiian language community as a potential model for Indigenous communities that choose traditional and contemporary pathways.
\end{abstract}

Keywords

Indigenous language revitalization, Hawaiian language, digital technology

\section{Introduction}

In spite of technological advancements and the proliferation of digital technology, many Indigenous peoples ${ }^{1}$ do not have equal and sustained access and infrastructure to digital technology in comparison to the global world. It is quite difficult to imagine the survival of Indigenous languages without support from digital technologies, with their ability to record, preserve, analyze, manipulate and transmit languages in a myriad of ways. Furthermore, as existing technologies are reinvented and new technologies emerge, additional contexts for language use surface in social media, apps, and virtual reality. Many

\footnotetext{
${ }^{1}$ According to the UN (n.d.), it is more useful to "identify, rather than define indigenous peoples. This is based on the fundamental criterion of self-identification as underlined in a number of human rights documents". Although there is no universal definition for "Indigenous", the UN's understanding is based on the following:

- $\quad$ self-identification as Indigenous people at the individual level and accepted by the community as their member.

- Historical continuity with pre-colonial and/or pre-settler societies

- $\quad$ Strong link to territories and surrounding natural resources

- Distinct social, economic or political systems

- Distinct language, culture and beliefs

- Form non-dominant groups of society

- Resolve to maintainand reproduce their ancestral environments and systems as distinctive peoples and communities.
}

For further discussion about Indigeneity, see Corntassel (2003) and DeLugan (2010). 
barriers and considerations in relation to language and digital technology exist for Indigenous peoples who have and continue to be exploited.

This paper discusses some of the barriers, complexities, and opportunities Indigenous peoples face when engaging in language revitalization efforts-from the past and into the present - and how these factors contribute to the adoption, adaptation, or abandonment of digital technology. I begin with framing the context of Indigenous languages in what is currently the United States and Canada to underscore their lived and current realities in comparison to colonial and world languages. The next section introduces the uptake of digital technology for Indigenous language learning, while touching upon the themes of equity, access and engagement. I conclude with a case study of the adoption of digital technology and its use in the Hawaiian language community-where I am fromas a potential model of hope for those Indigenous communities that choose both traditional and contemporary pathways.

\section{Setting the Indigenous Context in a Globalized World: United States and Canada}

According to the United Nations (n.d.), more than 370 million Indigenous people live in 70 countries around the world. Of the estimated 7,000 languages spoken today, some languages are spoken across broad geographic areas and used across a range of technology platforms. Indigenous languages, by comparison, have much smaller language communities, and the majority of Indigenous languages spoken today are endangered and at risk of language dormancy or language death. Many Indigenous communities around the world have experienced language loss as a result of genocide, colonization, assimilation, and national policies. With a population decline, knowledge of unique cultures, languages, histories, and worldviews are lost. However, the exponential rate of loss of Indigenous languages has been countered by local grassroots efforts to bring sleeping and endangered languages back to fruition.

The history of Indian boarding schools in the United States began in the seventeenth century with mission schools-boarding schools' predecessors, which were subsidized by the government from 1810 to 1917 (Archuleta, Child \& Lomawaima, 2000). In the 1860s, a federal school system for Native Americans was established, and in 1879 the first offreservation Indian boarding school, Carlisle Indian School (in Carlisle, Pennsylvania), was opened under the auspices of General Richard Henry Pratt. His well-known quote captures his sentiment toward American Indians: "kill the Indian in him, and save the man" (Barrows, 1892). More than 150 institutions across the United States were set up in an effort to eliminate any sign of Native Americans' unique cultural heritage, tradition, and language (Adams, 1995). This resulted in more than 100,000 children being forcibly removed from their homes-separating them from parents, siblings, and other family members (Lajimodiere, 2014).

A parallel history was experienced in Canada with government-sponsored religious schools - residential schools - that were established to assimilate Indigenous children into Euro-Canadian society. Mohawk Institute, the first residential school as defined by the Indian Residential Schools Settlement Agreement, opened in 1831 in Brantford, Ontario (Legacy of Hope Foundation, n.d.). By 1876, the Indian Act granted the Canadian government control over Indigenous peoples' lives, lands, and their natural rights and resources. While more than 150,000 First Nations, Inuit, and Metis children attended residential schools across Canada, more than 3,000 children died while in the school system 
(Truth and Reconciliation Commission of Canada [TRC], 2015). A countless number of children still remain unaccounted for.

These boarding and residential schools across North America and other countries have had a detrimental impact on the health and wellbeing of survivors and their families. Letters, testimonies, narratives, memoirs, and documentaries capture the trauma that was endured by children - now mature adults and elders - who were reprimanded and verbally, physically, and emotionally punished if they were caught speaking their Indigenous language. As a consequence, the trauma has been passed on to the next generationintergenerational survivors - who continue to deal with the repercussions of these boarding and residential school experiences.

Some current policies limit, and in some cases eliminate, instruction in the Indigenous language, thereby shifting to English as the dominant language. Specifically, national and regional language policies regulate the language use in social areas, such as the government, schools, and workplace, and so forth. Historically, policies imposed on Indigenous speakers prohibited the use of their Native language. For example, Act 57, section 30 of the 1896 Laws of the Republic of Hawai'i banned the use of Hawaiian language as a medium of instruction in public and private schools. Although it was not illegal to use Hawaiian in other contexts, the ban contributed to the decline of Hawaiian language speakers. Indigenous language communities suffered similar consequences within the mainland United States and worldwide (Smith, A. 2009). Foreign linguistic and cultural ideologies imposed upon Indigenous communities have contributed tremendously to the widespread use of English, often by discouraging the use of the Native language. However, for some Indigenous peoples, the fire within them has not extinguished and they "continually pick at the lock" (Zepeda, 2008, p. 64) in an effort to reclaim and revitalize their ancestral language and culture.

A renaissance movement among Native Americans in the United States surged in the late 1960s and early 1970s, resulting in a generation who received an education primarily outside of American Indian boarding schools and who later became the first from their respective communities to graduate from universities with a baccalaureate, master's, doctorate, or professional degree (Lincoln, 1983). These Indigenous scholars cleared a path and provided direction for future generations to continue in their footsteps and push the boundaries of mainstream education. Decades later in 1990, the United States passed the Native American Languages Act (NALA) Public Law 101-477 to "preserve, protect, and promote the rights and freedom of Native Americans to use, practice, and develop Native American languages” (US Congress, 1990, Section 104 [1]). In 1992, the NALA Public Law 102-524 was approved "to assist Native Americans in ensuring the survival and continuing vitality of their languages” (US Congress, 1992, Section 2/Sec 803C [a2]), providing some funding for various language revitalization programs, initiatives, and activities. In 2006, the Esther Martinez Native American Language Preservation Act (Public Law 109-394) further provided "for the revitalization of Native American languages through through Native American language immersion programs” (US Congress, 2006, para. 1). While the aforementioned Acts have advanced and supported Native American languages, many Indigenous languages are still under duress due to the English-only movement, the adoption of English as the official language of states, and No Child Left Behind (Public Law 107-110). 
Although the United States does not have an official language at the federal level, two states have adopted local Indigenous languages as official state languages. In 1978, Hawaiian became one of the official languages of the state of Hawai 'i, alongside English. More recently in 2014, the House Bill 216 designated twenty Alaska Native languages as official languages of Alaska: Inupiaq, Siberian Yupik, Central Alaskan Yup'ik, Alutiiq, Unangax, Dena'ina, Deg Xinag, Holikachuk, Koyukon, Upper Kuskokwim, Gwich'in, Tanana, Upper Tanana, Tanacross, Han, Ahtna, Eyak, Tlingit, Haida, and Tsimshian. Once forbidden, these languages now hold the same legal recognition as English. Similarly, two territories in Canada-Northwest Territories (NWT) and Nunavut-each passed the Official Languages Act (OLA) to include Indigenous languages (in 1990 and 2008, respectively). Alongside English and French, the Northwest Territories' OLA recognizes Chipewyan, Cree, Gwich'in, Inuinnaqtun, Inuktitut, Inuvialuktun, North Slavey, South Slavey, and Tlicho as official languages, and the Nunavut OLA recognizes Inuktitut and Inuinnaqtun as official languages (Office of the Commissioner of Official Languages, 2018). Although no such national act exists in Canada to date, Prime Minister Justin Trudeau announced in 2016 that the federal government will be proposing an Indigenous Languages Act.

On an international level, the World Summit on the Information Society (WSIS) adopted a set of principles in 2003 stipulating that particular attention be "given to the special situation indigenous peoples, as well as to the preservation of their heritage and their cultural legacy” (International Telecommunication Union [ITU], 2003, p. 3). The principles indicate that information and communication technology "applications should be user-friendly, accessible to all, affordable, adapted to local needs in language and cultures, and support sustainable development” (ITU, 2003, p. 7) that benefits all aspects of life. Furthermore, the principles specify that "the creation, dissemination and preservation of content in diverse languages and formats must be accorded high priority in building an inclusive Information Society" (ITU, 2003, p. 7), thereby contributing to local and regional social and economic development. In 2007-a few years after the adoption of these WSIS principles - the United Nations Declaration on the Rights of Indigenous Peoples (UNDRIP) was adopted by the General Assembly (United Nations, 2008) with a majority of states in favor. The articles in UNDRIP state that Indigenous peoples have the individual and collective right to revitalize, use, develop and transmit to future generations their Indigenous languages (13.1); to establish, control and provide education in their Indigenous languages (14.1); and to establish their own media in their Indigenous languages and to have access to all forms of non-Indigenous media (16.1). The adoption of UNDRIP — not originally supported by the United States, Canada, Australia and New Zealand-has (re)empowered Indigenous peoples to (re)learn their languages amidst dwindling human resources. The Secretary-General of the United Nations, Ban Ki-moon, described the adoption of UNDRIP as "a historic moment when UN Member States and indigenous peoples have reconciled with their painful histories and are resolved to move forward together on the path of human rights, justice and development for all” (United Nations News, 2007). All four initially opposing countries later changed their positions to 'support' the UNDRIP as a non-legally-binding document.

For many endangered and Indigenous languages, intergenerational language transfer has been disrupted in the homes and communities that were once governed in and through those languages. Schools that once stripped linguistic and cultural heritage from 
young children are now key sites of revitalization where educators actively integrate Indigenous knowledge into the curriculum. Some Indigenous languages are now taught in classrooms where they were once banned. Schools such as Nāwahīokalaniopu' $u$, in Kea 'au on the island of Hawai' $i$, operate and function entirely in 'Ōlelo Hawai ${ }^{2}{ }^{2}$ from kindergarten through grade twelve. Thus the potential impact of digital inclusion for Indigenous peoples living on reserves, in remote and rural areas, and in urban cities is perhaps greater than we can imagine for Indigenous language reclamation, revitalization, and education.

\section{Digital Technology and Indigenous Language Learning}

Digital technologies have the potential to be powerful tools that connect and bring speakers and learners together virtually from local communities, rural and urban settings, and the rest of the world-providing opportunities to access and engage with communitybased language revitalization and education efforts. The use of digital technologies in Indigenous communities is perceived as a double-edged sword and met with mixed emotions of suspicion, skepticism, but also hope-raising questions about its benefits and drawbacks. Nonetheless, Indigenous peoples, having adopted and adapted modern tools since their first contact with foreigners, have continued the same process with digital technologies. Digital technologies used to document, archive, and teach language have also contributed to privacy concerns, cultural appropriation, misuse of control, and the manipulation (Delgado, 2003) of cultural knowledge. The recognition of digitial technology as both a barrier and enabler of language revitalization forms the basis for discussions on how new technology can be used to support Indigenous language education efforts while maintaining cultural integrity (Galla, 2016).

The digital revolution is recognized as a dimension of progression, development, and globalization. However, for some Indigenous peoples, digital technology is yet another form of colonization that reinforces the Western-based dominant modes of knowledge systems and worldviews (Dyson, Hendricks, \& Grant, 2006). Chief Isadore Day of the Serpent River First Nation reminds us that our Indigenous cultures originate from oral tradition, and to ensure that our languages prosper, we need to engage in face-to-face conversations with our youth, reconnect with the land, and turn off and leave our digital technologies behind (as cited in Scannell, 2012). Pueblo youth in the U.S. Southwest have questioned the applicability of digital technology at a time when tribal policies are divided. Some Pueblos prohibit writing and the distribution of their Indigenous language in any form-visual, print or social-while other Pueblos are open to contemporary literacy practices (Huaman, Martin, \& Chosa, 2016). However, studies have highlighted the positive aspects of technological use in Indigenous communities, including the new opportunities to archive, preserve, document, revitalize and maintain Indigenous languages (Carpenter et al., 2016; Dyson et al., 2007; Galla, 2009, 2016). Indigenous youth have increasingly become active users of digital technology and producers of digital media in an effort to archive, promote, document, and learn their Indigenous languages (see Carew, Green, Kral, Nordlinger, \& Singer, 2015; Cru, 2015; Kral, 2010, 2011, 2012; Rice, Haynes, Royce, \& Thompson, 2016; Ryan, 2016; Wyman, McCarty, \& Nicholas, 2014). However, as Featherstone (2013) notes, providing access to technology, the Internet, and

2 'Ōlelo Hawai'i refers to the Hawaiian language. 
opportunities to engage with new technologies will not lessen or solve the digital divide (within communities, between communities and with the outside world) without an understanding of how technology is adapted, adopted, developed, promoted, or abandoned. Equity and Inclusion of Indigenous Languages in a Digital World

The lack of support and protection of Indigenous peoples against a global economy reduces the visibility of true cultural and linguistic diversity. The diversity on the Internet primarily reflects the major world languages that are spoken across countries or continents - in effect exposing digital and knowledge divides, digital technology inequities, and the differential uptake of digital technologies. Though languages with smaller populations of speakers should have an equal chance to promote and use their language as the medium of communication in their homes, schools, government, and on the Internet, not all languages are treated equitably. Colonial ideologies, structures, and language policies have limited the use of Indigenous languages in educational as well as public domains. Meaningful linguistic policies established for the 'real world' must now also take into account the 'virtual world.' Pimienta, Prado, and Blanco (2009) categorize different language groups_-including main languages, official languages, local languages, languages of developing countries, languages at risk of disappearing, and so forthindicating how the Internet in fact affects various language communities. These distinctions help to determine how language policies - affecting both real world and virtual environments - can respond to languages of different status, size, and stature.

Indigenous communities have been plagued by many social and economic conditions, some of which include disparities in technology. In the last twenty years, a handful of reports have provided insight into technology use, access, and capacity in often overlooked constituencies, including Indigenous language communities. Riley, Nassersharif, and Mullen (1999) indicate that rural Native communities (with populations of less than 2,500) in the United States are under resourced and continue to struggle with basic utilities: $12 \%$ lack electricity and 23\% lack gas. Of rural Native households, 39\% are equipped with telephone service (in comparison to 94\% of rural non-Native homes), 22\% have cable television, 9\% have personal computers, and 8\% have Internet access (Riley et al., 1999). The shortage of roads restricts these communities from traveling to receive the training necessary to maintain and operate home computers. The lack of computer facilities and Internet service providers, along with economic insufficiencies, also hamper the use of digital resources.

In 2000, it was estimated that 276 million people worldwide were Internet users, with a growth rate of approximately 150,000 people per day (United Nations, 2000). In $2007,17.5 \%$ of the world population (1.15 billion) was connected to the Internet (Pimienta et al., 2009). In 2009, 20\% of the population (1.2 billion) had access to the Internet (United Nations Educational, Scientific and Cultural Organization [UNESCO], 2009), and by 2013 that figure had increased to over 2.7 billion people, corresponding to $39 \%$ of the world's population (ITU, 2013). In developing countries, households were three times as likely to have a TV than a computer or Internet connection, in comparison to developed countries that were only 1.3 times as likely (ITU, 2013). By the end of 2016, 47\% of the global population (3.5 billion) were Internet users; one billion were users in developed regions, in comparison to 2.5 billion users in the developing world (ITU, 2016). These statistics indicate that there is still a majority of people who are not yet online and connected to the Internet. Priority and action must be given to those that remain unconnected to improve the 
accessibility and affordability of services and to ensure an inclusive information society for all. There is no comprehensive data that represents digital technology use among all Indigenous peoples; however, there are reports that generally describe the situation in relation to Native American communities in the US (Casey, Ross, \& Warren, 1999; Morris \& Meinrath, 2009; United States Congress, Office of Technology Assessment, 1995).

For Indigenous languages to thrive in a contemporary society among world languages, the currently under-resourced languages themselves must also be supported in all domains of life. To support language growth, the language(s) needs to be used in the home and expanded to broader areas including education, work, community, government, media, business, and out-of-school environments-locally, regionally, and nationally (Fishman, 1991; Hinton, 2001). However, due to historical factors and a lack of prioritization for Indigenous languages, exposure to language has "severely restricted use in the wider community” (Slaughter, 1997, p. 2). Digital technology has created new domains for engagement and interaction with Indigenous languages. The online presence of Indigenous languages raises their "social prestige in a community" (Ward \& Genabith, 2003) in some way, such that these languages are worthy, relevant, and perceived as somewhat "normal" amidst languages of wider communication (Galla, 2010, 2016). The goal should be to work toward normalizing the language in the local community, where the function of the Indigenous language matches or supersedes dominant and colonial languages in conversation, in education, arts, health, government, literature, and media, and in physical and virtual spaces. Digital technology provides the opportunity for Indigenous language to co-exist and share 'space’ with dominant languages.

\section{Access to and Engagement with Indigenous Languages}

Access and cultural appropriation. In addition to the colonization of Indigenous peoples, globalization has altered how information and knowledge are accessed, exchanged, and engaged with. New digital technologies and the Internet have created opportunities as well as challenges for Indigenous peoples who are trying to maintain the sacredness of their Indigenous culture, language, and traditions. Mobile technologies, social networking platforms, and the Internet have brought knowledge from local communities to the global stage, sometimes without consent from the Indigenous communities. This practice of non-consent is not new.

Indigenous peoples are said to be the most researched population in the world. Researchers - typically from outside the community - often gain knowledge and academic qualifications with little to no benefit reciprocated back to the Indigenous community. This practice continues today, among various disciplines in even the most prestigious universities. This abuse of power and "pursuit of knowledge is deeply embedded in the multiple layers of imperial and colonial practices” (Smith, L. T., 1999, p. 2).

Academic institutions have implemented ethics review boards to carefully examine and ensure that research with Indigenous peoples, culture, language, heritage, intellectual property and so forth follow appropriate protocols gauged by the participating university(ies) and the Indigenous community(ies) and peoples that are involved. In addition to knowledge mining, 
It appalls us that the West can desire, extract and claim ownership of our ways of knowing, our imagery, the things we create and produce, and then simultaneously reject the people who created and developed those ideas and seek to deny them further opportunities to be creators of their own culture and own nations. It angers us when practices linked to the last century, and the centuries before that, are still employed to deny the validity of indigenous peoples' claim to existence, to land and territories, to the right of self-determination, to the survival of our languages and forms of cultural knowledge, to our natural resources and systems for living within our environments. (Smith, L. T., 1999, p. 1)

This regurgitation of knowledge, repackaged and camouflaged as "new knowledge," is yet another way that Indigenous voices have been ignored and devalued. Although digital platforms provide venues for potential local knowledge exchange and communication, this same technology has suppressed Indigenous alternatives and worldviews (Mander, 1991)-rendering "local knowledge invisible by declaring it non-existent or illegitimate...destroying the reality which they attempt to represent” (Shiva, 1993, p. 12). Furthermore, "with each new generation of technology, and with each stage of technological expansion into pristine environments, human beings have fewer alternatives and become more deeply immersed within technological consciousness" (Mander, 1991, p. 32). Cultural appropriation is pervasive and continues to play out in various forms-as evidenced, for instance, by Victoria's Secret fashion shows adorning models in Native American-inspired headdresses and Disney's Moana 'brownface' costume of Maui. These examples commodify Indigenous peoples and cultures, signifying that Indigenous identities can be chosen and purchased. The pursuit for knowledge is pervasive in this digital age; at times it may be easy to forget that "newfound" knowledge and artifacts are sacred to individuals and communities. Not all knowledge is authorized "public" knowledge - even if it is made "accessible" in this digital age.

Engagement of youth. Krauss (1998; see also Krauss' testimony as cited in US Senate Committee on Indian Affairs, 2000) reported that youth in many Indigenous communities in North America were not learning their Indigenous language. Recent studies indicate that youth subgroups are reconnecting to their heritage and are learning their Native languages through intergenerational language transmission, community-based language efforts, university classes, and digital technology initiatives (Wyman, 2012; Wyman, Galla \& Jimenez-Quispe, 2016; Wyman, McCarty \& Nicholas, 2014). Utilizing digital technology has the power to influence youth in learning their language (McHenry, 2002; Ward, 2004); by providing a non-judgmental environment for learners to actively engage in the language without the pressure of being grammatically correct, it allows them to "[avoid] demonstrating inadequate personal capability" (Te Huia, 2013, p. 15) in front of teachers, peers, family members, and elders (Hermes \& King, 2013; Vluger, Knott, McDonald, \& Hall, 2009) who hold a variety of linguisitc and cultural expextations. Anxiety can be devitalizing to language learners, especially to those who identify and have ancestral ties to the language and do not want to be seen as inauthentic participants of their culture (Te Huia, 2013). Research shows decreased anxiety in language learners who actively engage in learning when using digital technology (Liu, Moore, Graham, \& Lee, 
2003). Digital technology lowers their affective filter because there is no risk of embarrassment or ridicule.

Digital technology provides a new medium to interact through and with the language and has an appeal to youth (Galla, 2010, 2016). The skills that youth acquire as presumed "digital natives" (Brown \& Czerniewicz, 2010; Prensky, 2001) are prized assets that contribute to community-based language education and revitalization efforts. Although some language speakers, including elders, may not always be as receptive to or comfortable with using digital technology for documentation or revitalization, the future of Indigenous languages lies with youth and the future generations. Community-based language revitalization efforts have the potential to bring together youth, who are more comfortable with digital technology as users and producers, and elders, who are language and cultural knowledge holders, to work collaboratively on language initiatives and projects - thus allowing for an intergenerational exchange of ideas, skills and learning opportunities (Galla, 2012). Bridging these subgroups creates a collaborative environment in which both language and technological skills are developed (Warschauer, 1998).

Documentation and materials development. Technology has been used as a means to document, preserve, and archive Indigenous languages — as evidenced by the use of wax cylinders, reel to reel tapes, LP records, cassette tapes, CDs, and digital audio files. With each language speaker that passes on to the spiritual domain, bits and pieces of discoursenuances, sounds, expressions, metaphor, and gestures—are lost, sometimes curtailing a direct experience with language. The aforementioned audio resources have captured stories, chants, songs, genealogies, ceremonies and other important activities conducted in the language of some Native speakers who are no longer with us. Their individual voices (along with background and environmental noises) are preserved in analog and/or digital formats-providing opportunities for families, community members, and language learners to hear authentic examples of speech through different media (Galla, 2016).

Digital technology has projected and carried Indigenous voices and stories across local traditional territories and throughout foreign lands. But, not too long ago, students and citizens were enculturated into a national ideology of homogeneity that has miseducated, misinformed, dehumanized, overgeneralized, and romanticized Indigenous peoples. Indigenous peoples have been repeatedly left out of the curriculum, or, at most, highlighted on one page in a textbook - to describe, for example, the diversity of Native Americans in the United States, which comprise of more than 500 communities and 100 languages. It is not a surprise that much of what has been published and disseminated about these communities has historically been from the perspectives of non-Indigenous peoples (Ingle, 2003). During the era of the printing press and publishing houses, there was a heavy reliance on "others" or the "outside" to print literature and resource materials such as textbooks, dictionaries, grammar guides, bibles, newspapers, and books. With digital technology, communities are now equipped with common tools-including word processing and desktop publishing software- that give authority and empower Indigenous peoples to author, illustrate, print and publish their own language and culture materials (Bernard, 1992; Galla, 2010, 2016). A significant challenge identified by language educators of endangered and Indigenous languages is the lack of pedagogical, culturally relevant, appropriate, and authentic materials (Warschauer \& Donaghy, 1997) that depict the people, language, and culture in a non-stereotypical way. The ability to generate 
language materials and resources "in-house" - or by, for, and within the communityallows for control over the creation, development, production, publication, and distribution each and every step of the way.

Due to limited human resources, digital processes and products help learners gain access to culturally informed and authentic linguistic and cultural resources wherever they may reside. The use of digital technology has proved to be an efficient and effective practice to create, revise, and share print and digital materials with intended audiences across waterways and lands. With appropriate software, the development, production, printing, publishing, and distribution of language materials and resources can be achieved at relatively low cost (Villa, 2002). The implementation of digital technology in language revitalization and education efforts also requires appropriate planning to ensure that the technology supports language learning in a manner that is appropriate to the Indigenous community's cultural and linguistic realities (Galla, 2016; Villa, 2002). The multimodal ways of learning Indigenous languages should be seen as complementary to print-based media and as an "opportunity to contribute a newly invigorated literate tradition and to enrich our available means of signification” (Hull \& Nelson, 2005, p. 226).

Expanding language domains. The needs of Indigenous language learners are distinct from other language learners such that Indigenous languages are rooted in specific geographic areas (Adley-SantaMaria, 1997). For example, 'Ōlelo Hawai'i (Hawaiian) is spoken in Hawai'i, Te Reo Māori (Māori) in Aotearoa (New Zealand), Diné Bizaad (Navajo) in the Southwest region of the United States in Arizona, New Mexico, Utah, and Colorado, and hən'q̇əmin̉əm (Musqueam) is spoken in Vancouver and the surrounding areas in British Columbia, Canada. Although these languages may have intermittent speakers scattered throughout the world, these languages are Native to their traditional homelands. If Spanish were no longer spoken in Spain, the language would still be viable in areas such as the U.S., the Caribbean, Mexico, Central America, South America, Rapa Nui (Easter Island), areas of Africa, and so forth. However, until the advent of the Internet, Indigenous peoples did not have the linguistic luxury of finding a population of speakers of their language in other parts of the world. Now, due to digital technology and the Internet, Indigenous languages have traversed transnational borders and extended to new domains (geographical and digital), allowing greater accessibility to Indigenous language learners and to the world (McHenry, 2002). Synchronous technology allows a community of practice — who may not be situated in the same region, land, or time zone - to gather and correspond in real time. Along with traditional domains of language use, Indigenous languages can be experienced in digital and virtual domains that offer an immersive experience and a reconnection to the land where the language resides. While new and robust technologies offer exciting possibilities for language learning and expansion into different domains, some Indigenous communities choose to keep their languages private for their community and its members—a language choice and right that they have.

\section{Hawai ' $i$, 'Ōlelo Hawai 'i and Digital Technology}

Similar to many Indigenous communities in North America, 'Ōlelo Hawai' $i$-an endangered and Indigenous language of Hawai' $\mathrm{i}$ - has declined in the number of speakers since contact with outside world. Prior to Western contact in 1778, there were 800,000 Hawaiians that populated the islands (Warner, 1999) all of whom were native speakers of 
Hawaiian. In 1893, the U.S. government, led by American business interests, participated in the overthrow of the Hawaiian Monarchy that led to the annexation of the islands. In 1896, HRS 298-2 was passed, prohibiting the use of Hawaiian as the medium of education. By 1900, the number of Hawaiian speakers decreased to 37,000 mother tongue speakers. Native Hawaiian and plantation immigrant children began to replace Hawaiian as the lingua franca among themselves with pidginized English under the new political system.

After statehood in 1959 and under the influence of the civil rights movement, people in Hawai' $i$ began to reexamine existing inequities in local cultural and social norms as well as the lack of attention to Hawai'i's own culture and history. This awakening contributed to a surge of renewed attention to Hawaiian ways of knowing, being, and doing - a rediscovery of identity, as well as traditional forms of navigation, land rights, music, hula, and language referred to as the Hawaiian Renaissance. The strength of the Hawaiian Renaissance movement of the 1970s, as well as the influence from Māori in Aotearoa, contributed to the revitalization of the Hawaiian language. In 1972, Ka Leo Hawai' $i$ - a radio program hosted by Larry Kimura for 16 years-broadcasted Hawaiian language interviews and conversations with mānaleo (native speaker, 'inherited language'). Six years later, in 1978, Hawaiian was adopted as an official language of the state, alongside English. Prior to the opening of Hawaiian Language Medium Education (HLME) schools, there were 1,000 native speakers, all of whom were elders 60 years of age or older (typically born before 1920) - or were members of a tiny remnant community on the isolated island of $\mathrm{Ni}$ 'ihau, where approximately 200 residents of all ages were first language speakers of Hawaiian.

In 1983, 'Aha Pūnana Leo ('APL), a non-profit organization, was established by a small group of educators. With a handful of educators, elders, and families all committed to the linguistic cause, they focused their efforts on nurturing a new generation of speakers that would be able to describe the world through the lens of their language and culture, as well as master English and other languages. Thus began the Hawaiian language revitalization movement. At that time, Māori language educators in Aotearoa with ties to Ka Leo Hawai' $i$ had begun to provide preschool aged children with the opportunity to learn Māori in schools called Kōhanga Leo (language nest). 'APL adopted the idea and established Pūnana Leo, where "just as young fledglings are fed directly from the mouths of their mothers, Hawaiian language is fed into the ears of our 3- and 4-year-old students from the mouths of the Hawaiian language speakers around them" ('Aha Pūnana Leo ['APL], n.d.). At the start of the language movement, there were fewer than 40 children under the age of 18 fluent in Hawaiian ('Aha Pūnana Leo \& Ka Haka 'Ula O Ke'elikōlani, Ke Kulanui o Hawai'i Hilo ['APL \& KH'UOK], 2009). In 1992, within the Native Hawaiian population of 220,747, between 500 and 1,000 were native speakers of Hawaiian (Wilson, 1998).

The passion exemplified by this group resulted in the establishment of infant/toddler programs, language nest preschools, kindergarten through grade twelve education, and university programs, all of which are referred to collectively as HLME from cradle to career. The most recent statistic on speakers of non-English languages in Hawai' $i$ report that 18,400 people above age five speak Hawaiian at home, making Hawaiian the sixth most common non-English language reported as spoken in the home (State of Hawai'i, 2016). These statistics show a distinctive concentration of Hawaiian speakers between the ages of 5 and 17, with 5,200 reporting to speak Hawaiian in this age group. 
While certainly not all those who self-reported use of Hawaiian in the home were likely fully proficient speakers of Hawaiian, the growth of Hawaiian speakers in recent years clearly indicates a movement toward an increased use of Hawaiian in the home and positive identification with use of the language.

\section{'Ōlelo Hawai ' $i$ in the Digital Age}

Hawaiian language educators that were part of the grassroots Hawaiian language revitalization movement had a simple goal in mind: to bring 'Ōlelo Hawai'i back to fruition. The Hawaiian language success in the middle of the Pacific Ocean has attracted Indigenous language educators from across the world to see how a small group of educators were able to resuscitate a language so that it is living, vibrant, and now spoken as a first language by two generations. Hawaiian language educators looked immediately to elders, cultural memory, hula, oli (chant), mele (song), archived documentation, and to our natural environment to (re)learn the language. With widespread digital computer technology in homes, schools, and workplaces on the horizon, language educators were curious to know how the new tools could be exploited to their full potential to allow Hawaiian language to prosper and benefit the growing Hawaiian language community. The potential for digital technology at the time was uncertain, but "to ignore modern technology would suggest that our language doesn’t belong” (Donaghy, as cited in Bailey, 2009, para. 7). As interest in the language movement began to take shape, families across the Hawaiian island chain wanted opportunities for their children to be immersed in Hawaiian language from an early age. Hawaiian immersion programs within English medium schools, and HLME schools soon opened up on various islands to serve the demand. However, there were not enough proficient Hawaiian language teachers - a challenge experienced by many Indigenous language programs. It was important to maintain a quality Hawaiian language education and also ensure that students received a comparable education to their English-speaking counterparts.

Since there were only small pockets of Hawaiian language speakers and educators across the Hawaiian Islands, it was extremely important to maintain consistency in the language, curriculum, and lessons across the Hawaiian language classrooms. Hawaiian language educators adopted and adapted tools to facilitate communication, networking, collaboration, and learning at a time when human and material resources were limited. They turned to the Internet to help disseminate authentic and culturally relevant language materials. One such technology was Leokī (an electronic bulletin board system meaning 'powerful voice'), developed in 1995 by Hale Kuamo'o Hawaiian Language Center ${ }^{3}$. Though no longer used, Leokī was known as one of the first bulletin board systems to operate exclusively in an Indigenous language (Hale, 1995; Warschauer \& Donaghy, 1997) — providing online support for Hawaiian language educators in Hawaiian immersion schools, Hawaiian language medium schools, and the broader community. Leoki allowed users to upload and download files, read news, exchange messages through email, and

${ }^{3}$ The Hawai'i State Legislature established Hale Kuamo'o in 1989 as a division of Ka Haka 'Ula O Ke'elikōlani (College of Hawaiian Language) at the University of Hawai'i Hilo. Some of the focus areas of the Center includes the development of language materials for use in Hawaiian language medium schools, production and distribution of materials for print media, radio, television, social and digital media and so forth, and the connection of local and global communities through internet-based websites such as Ulukau (a Hawaiian Digital Library) (Univerity of Hawai’I [UH] Hilo, 2017). 
interact via message boards-all in the Hawaiian language. Leokī brought a network of Hawaiian language community members closer and helped to defray some of the costs of traveling to neighboring islands. Teachers valued Leokī because it allowed them to share the lesson plans and activities they developed with each other, contributing to a growing library of new resources serving the language community (Hale, 1995).

In the early years of the language revitalization movement, Hawaiian immersion schools adapted English language textbooks and children's books using the translate-cutand-paste method. Hawaiian translations were typed, printed, copied, cut, and pasted over the English language of each text. This technique, though productive, imposed a perspective from outside the Hawaiian Islands (L. Wong, as cited in Warschauer, 1998). Language and literacy materials were still needed to represent, reflect, and honor Hawaiian epistemology; that is, the Hawaiian ways of knowing, being, and doing that are represented from an emic perspective. Teachers along with students have contributed to the development of materials that provide authentic texts of Native Hawaiians both in traditional and contemporary settings.

In 2002, Apple released Mac OS X 10.2, which included the Hawaiian keyboard, sorting routines, and some translated strings (mostly date and time related) (Donaghy, n.d.b, 2014). This was a huge development in the Hawaiian language community, as it provided some consistency between digital technology users who had access to Mac computers. Thereafter, any Mac operating system that was released included the Hawaiian keyboard. In 2004, a partnership between Alu Like (a private nonprofit service organization that assists Native Hawaiians in their efforts to achieve social and economic self-sufficiency) and Ka Haka 'Ula O Ke'elikōlani (KH'UOK) College of Hawaiian Language at the University of Hawai'i Hilo helped to establish Ulukau - the Hawaiian Electronic Library — that made primary resources available for the "use, teaching, and revitalization of the Hawaiian language and for a broader and deeper understanding of Hawai' $i$ ' ('Ōiwi TV, 2009). These Hawaiian language resources have included the bible, dictionaries, grammars, newspapers, genealogical records, reference materials, and photographs (dating from the early 1800s to 1900s), as well as recent and contemporary publications of academic Hawaiian language journals, curriculum guides, and fiction and non-fiction books for early learners to proficient language speakers. The resources on Ulukau can be viewed online or downloaded as PDF files, and are accessible to the wider community. An audio resource that is available on Ulukau are the Ka Leo Hawai' $i$ recordings that include 393 recorded programs (totaling 502 hours of original recordings on 7-inch reels).

In 2009, Apple added Hawaiian support in its operating system for the iPhone 3 (iOS 3) that included two diacritical markers: the kahakōahako9, Apple added Hawaiian support in its operating system for the iPhone 3 (iOS 3) t'okina (glottal stop), a consonant that indicates a break in a sound or word (Donaghy, n.d.-a). That same year, Google in 'Ōlelo Hawai' $i$ was also released as part of the Google in Your Language program, which encouraged the translation of Google products into minority and Indigenous languages. According to Kalena Silva, director of KH'UOK at the time, "Google is the most heavilyused search engine on the Internet, and from a practical and a symbolic standpoint, this interface puts Hawaiian on par with the many other languages that Google currently supports" (University of Hawai' $i$, 2009, para. 3). The interface and navigation when using Google Hawai' $i$ is in 'Ōlelo Hawai' $i$; however, individual search results appear in the 
original language. Although there was support for the use of Hawaiian diacritics in early versions of iOS-produced by pressing and holding down a vowel and choosing the appropriate diacritic combination - the Hawaiian keyboard and Hawaiian spellcheck was not packaged until the release of iOS 5 in 2011 (Donaghy, n.d.-a).

In 2012, a decade after Apple's initial support of Hawaiian language integration in its operating system, Microsoft launched Windows 8 with the Hawaiian keyboard layout, which included the kahakō, 'okina, and other localized resources (Donaghy, 2012). Keola Donaghy, formerly of $\mathrm{KH}^{\prime} \mathrm{UOK}$ and now a faculty member in the music department at the University of Hawai'i, Maui College, has been instrumental in the development of the aforementioned digital projects-work that has raised the visibility of 'Ōlelo Hawai' $i$ to stand alongside European and other major languages. He stated,

We're getting very close to the day that Hawaiian speakers will be able to take for granted the fact that they can simply type in Hawaiian when they buy a new computer, tablet, or smart phone without installing special software. (as cited in Donaghy, 2012, para. 6)

Keiki Kawai'ae'a, a faculty member and current director of $\mathrm{KH}^{\prime} \mathrm{UOK}$, added,

We are thrilled that Microsoft has recognized the significance of the Hawaiian language to its people, and how important it is for us to be able to use it on our computers. Given the high percentage of personal computers that ship with and run the Windows operating system, this is one of the most significant developments that we've made. (as cited in Donaghy, 2012, para. 8)

With support from Apple and Microsoft, the Hawaiian language is now supported across most platforms.

The rise of digital opportunities in 2012 continued with Bank of Hawai 'i's inclusion of Hawaiian as one of the language options at select ATMs, with the intention of expanding this option throughout Hawai'i (Silverstein, 2012) to serve the growing subgroup of Hawaiian language speakers. More recently in 2016, Hawaiian has been included as one of the languages offered in Google Translate. Since Hawaiian is an endangered and Indigenous language, Google relies on Hawaiian language speakers to contribute correct interpretations of words, phrases, and sentences to help improve Google Translate. Additionally, 'Ōiwi TV (accessible via cable and online) has been an instrumental media platform, producing documentaries, news, and multimedia content from a uniquely Hawaiian perspective-and often in 'Ōlelo Hawai'i. Its mission is to "leverage the power of media to create meaningful impact and experiences for Hawaiians, Hawai' $i$ and the rest of the world" ('Öiwi TV, 2017). These initiatives illustrate just a handful of the ways in which digital technology has supported the Hawaiian language community since the beginning of the Hawaiian language revitalization movement.

The integration of digital technology has provided access to culturally relevant and authentic materials, and has increased the domains in which the Hawaiian language is used and engaged. Hawaiian television programs with Hawaiian closed captioning, radio programming, audio books, CDs, DVDs, web-based products, online dictionaries, local news stations, language websites, movies, distance learning classes (i.e., Niuolahiki), 
search engines, an electronic bulletin board system (Leokī), the Electronic Library (Ulukau), music sites (i.e., Huapala) and podcasts, and live streaming of cultural events are among the outcomes of digital technology that have improved equity as well as access to and engagement with the Hawaiian language.

\section{Conclusion}

The journey for Indigenous communities toward language reclamation and revitalization is a long and arduous one, especially when there are no fluent speakers remaining. With the assistance of digital technology, many minority, endangered, and Indigenous language communities have entered new domains of communication. The Internet, along with digital and mobile technology, has changed the way knowledge is accessed, shared, and engaged with-providing communities with opportunities of hope for language revival.

Indigenous peoples are “coming to terms” with digital technology-finding ways to exploit these "new" technologies to promote and benefit language revitalization efforts in ways that were not available before. Digital technology is a medium that allows language learners and speakers - regardless of age - to access and engage with their Indigenous languages in traditional (e.g., home, school) as well as new domains (e.g., mobile devices, virtual reality, or foreign lands). Users and producers of digital technology also have the potential to contribute to community-based language revitalization efforts-developing documentation and materials that can be shared with members of the community both near and far. Nevertheless, digital technologies have also contributed to the pervasiveness of cultural appropriation that plague Indigenous peoples. Indigenous knowledge systems, language, and cultural elements are at risk of dilution, stereotyping, and manipulation when there is not an understanding of the sacredness of knowledge that belongs to individuals of these Indigenous communities.

Given some of these challenges, it is useful to look at the case of the Hawaiian language. Digital technology has provided language opportunities for the Hawaiian language to feel normal alongside language giants. For a relatively small language community in comparison to English, Hawaiian is making strides-and Hawaiian language advocates are exercising their rights to establish a presence in the digital world. "Hawaiian is good enough for every part of life. That is the sign of a healthy, living language" (Kawai'ae'a, as cited in Hale, 1995, para. 26). 'Ōlelo Hawai' $i$ is a living language that calls for its visibility in both the physical and digital world.

\section{References}

Adams, D. (1995). Education for extinction: American Indians and the boarding school Experience 1875-1928. Lawrence: University Press of Kansas.

Adley-SantaMaria, B. (1997). White Mountain Apache language: Issues in language shift, textbook development, and Native speaker-university collaboration. In J. Reyhner (Ed.), Teaching Indigenous Languages (pp. 129-143). Flagstaff, AZ: Northern Arizona University.

'Aha Pūnana Leo (n. d.). E ola ka 'ōlelo Hawai'i - The Hawaiian language shall live. Retrieved from http://www.ahapunanaleo.org

'Aha Pūnana Leo \& Ka Haka 'Ula O Ke‘elikōlani, Ke Kulanui o Hawai'i Hilo. (2009). Kumu honua mauli ola: He kālaimana‘o ho‘ona‘auao ‘Ōiwi Hawai‘i. Hilo, HI: 
'Aha Pūnana Leo \& Ka Haka 'Ula O Ke'elikōlani, Ke Kulanui o Hawai'i Hilo. Retrieved from http://www.ahapunanaleo.org/images/files/KHMO.pdf

Archuleta, M. L., Child, B. J., \& Lomawaima, K. T. (2000). Away from home: American Indian boarding school experiences, 1879-2000. Phoenix, AZ: Heard Museum.

Bailey, C. (2009, August). Google goes Hawaiian language with homepage. Hawai ' $i$ Magazine. Retrieved from http://www.hawaiimagazine.com/blogs/hawaii_today/2009/8/12/Google_homepa ge_search_Hawaiian_language

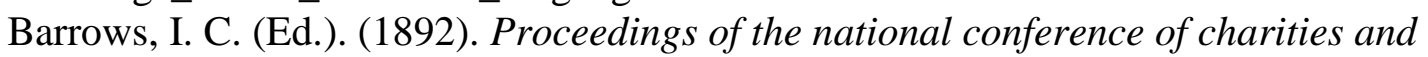
correction at the nineteenth annual session held in Denver, Colorado. Boston, MA: Press of Geo. H. Ellis. Retrieved from https://play.google.com/books/reader?id=dpJIAAAAYAAJ\&printsec=frontcover \&output=reader\&hl=en\&pg=GBS.PP11

Bernard, H. R. (1992). Preserving language diversity: Computers can be a tool for making the survival of language possible. Cultural Survival Quarterly, 16(2), 1321.

Brown, C. \& Czerniewicz, L. (2010). Debunking the 'digital native’: Beyond digital apartheid, towards digital democracy. Journal of Computer Assisted Learning, 26(5), 357-369. doi:10.1111/j.1365-2729.2010.00369.x

Carew, M., Green, J., Kral, I., Nordlinger, R., \& Singer, R. (2015). Getting in touch: Language and digital inclusion in Australian Indigenous communities. Language Documentation \& Conservation, 9, 307-323.

Carpenter, J., Guerin, A., Kaczmarek, M., Lawson, G., Lawson, K., Nathan, L. P. \& Turin, M. (2016). Digital Access for Language and Culture in First Nations Communities. Knowledge Synthesis Report for Social Sciences and Humanities Research Council of Canada. Vancouver, October 2016. 41 pages. Retrieved from https://heiltsuk.sites.olt.ubc.ca/files/2017/05/Digital_Language_Access_report_M ay2017.pdf

Casey, J., Ross, R., \& Warren, M. (1999). Native networking: Telecommunications and information technology in Indian country. Washington, DC: Benton Foundation. Retrieved from https:/files.eric.ed.gov/fulltext/ED430769.pdf

Corntassel, J.J. (2003). Who is Indigenous? 'Peoplehood' and ethnonationalist approaches to rearticulating Indigenous identity. Nationalism and Ethnic Politics, 9(1), 75-100.

Cru, J. (2015). Language revitalisation from the ground up: Promoting Yucatec Maya on Facebook. Journal of Multilingual and Multicultural Development, 36(3), 284296.

Delgado, V. (2003). Technology and Native America: A double-edged sword. In G. Solomon, N. Allen, \& P. Resta (Eds.), Toward digital equity: Bridging the digital divide in education (pp. 88-98). Boston, MA: Allyn and Bacon.

DeLugan, R.M. (2010). Indigeneity across borders: hemispheric migrations and cosmopolitan encounters. American Ethnologist, 37(1), 83-97.

Donaghy, K. (n.d.-a). Hawaiian support in iOS 5. [Web log post]. Retrieved from http://keoladonaghy.com/olelo-tech/hawaiian-support-in-ios-5/

Donaghy, K. (n.d.-b). Macintosh OS X. [Web log post]. Retrieved from http://keoladonaghy.com/olelo-tech/macintosh/ 
Donaghy, K. (2012, November 8). New Windows 8 operating system supports the Hawaiian language. [Web log post]. Retrieved from http://keoladonaghy.com/blog/2012/11/08/windows-8-supports-hawaiianlanguage/

Donaghy, K. (2014, March 29). The origins of Hawaiian language support in Mac OS and iOS: So you want to change the world? [Web log post]. Retrieved from http://keoladonaghy.com/blog/2014/03/29/the-origins-of-hawaiian-languagesupport-in-mac-os/

Dyson, L. E., Hendriks, M., \& Grant, S. (Eds.). (2007). Information technology and Indigenous peoples. Hershey, PA: Information Science Publishing.

Featherstone, D. (2013). The Aboriginal invention of broadband: How Yarnangu are using ICTs in the Ngaanyatjarra Lands of Western Australia. In L. OrmondParker, A. Corn, C. Forde, K. Obata, \& S. O’Sullivan (Eds.), Information Technology and Indigenous Communities (pp. 27-52). Canberra, Australia: AIATSIS Research Publications.

Fishman, J. A. (1991). Limitations on school effectiveness in connection with mother tongue transmission. In J. A. Fishman (Ed.), Reversing language shift: Theoretical and empirical foundations of assistance to threatened languages (pp. 368-380). Clevedon, PA: Multilingual Matters.

Galla, C. K. (2009). Indigenous language revitalization and technology: From traditional to contemporary domains. In J. Reyhner \& L. Lockard (Eds.), Indigenous language revitalization: Encouragement, guidance \& lessons learned (pp. 167182). Flagstaff, AZ: Northern Arizona University.

Galla, C. K. (2010). Multimedia technology and Indigenous language revitalization: Practical educational tools and applications used within Native communities (Unpublished doctoral dissertation). University of Arizona, Tucson.

Galla, C. K. (2012). Sustaining generations of Indigenous voices: Reclaiming language and integrating multimedia technology. World Indigenous Nations Higher Education Consortium Journal, 8(1), 59-67.

Galla, C. K. (2016). Indigenous language revitalization, promotion, and education: Function of digital technology. Computer Assisted Language Learning, 29(7), 1137-1151. DOI: 10.1080/09588221.2016.1166137

Hale, C. (1995). How do you say computer in Hawaiian? Wired, 3(8), 90-100. Retrieved from https://www.wired.com/1995/08/hawaii-2/

Hermes, M. \& King, K. A. (2013). Ojibwe language revitalisation, multimedia technology, and family language learning. Language Learning and Technology, 17(1), 125-144.

Hinton, L. (2001). Language revitalization: An overview. In L. Hinton \& K. Hale (Eds.), The green book of language revitalization in practice (pp. 3-18). San Diego, CA: Academic Press.

Huaman, E. S., Martin, N. D., \& Chosa, C. T. (2016). "Stay with your words": Indigenous youth, local policy, and the work of language fortification. Education Policy Analysis Archives, 24(52). http://dx.doi.org/10.14507/epaa.v24.2346

Hull, G., \& Nelson, M. A. (2005). Locating the semiotic power of multimodality. Written Communication, 22(2), 224-261.

Ingle, H. T. (2003). Connections across culture, demography, and new technologies. In 
G. Solomon, N. Allen, \& P. Resta (Eds.), Toward digital equity: Bridging the digital divide in education (pp. 75-87). Boston, MA: Allyn and Bacon.

International Telecommunication Union (2003). World summit on the information society-declaration of principles. Geneva: ITU. Retrieved from http://www.itu.int/net/wsis/documents/doc_multi.asp?lang=en\&id=1161|0

International Telecommunication Union (2013). Measuring the information society [executive summary]. Geneva: ITU. Retrieved from http://www.itu.int/pub/DIND-ICTOI-2013/en

International Telecommunication Union (2016). ICT facts and figures 2016. Geneva: ITU. Retrieved from http://www.itu.int/en/ITUD/Statistics/Pages/facts/default.aspx

Kral, I. (2010). Plugged in: Remote Australian Indigenous youth and digital culture. Center for Aboriginal Economic Policy Research, Australian National University. Retrieved from http://caepr.anu.edu.au/sites/default/files/Publications/WP/WP69_0.pdf

Kral, I. (2011). Youth media as cultural practice: Remote Indigenous youth speaking out loud. Australian Aboriginal Studies, (1), 4-16.

Kral, I. (2012). Text, talk, and technology. Bristol, UK: Multilingual Matters.

Krauss, M. (1998). The condition of Native North American languages: The need for realistic assessment and action. International Journal of the Sociology of Language, 132, 9-21.

Lajimodiere, D. K. (2014). American Indian boarding schools in the United States: A brief history and legacy. In W. Littlechild \& E. Stamatopoulou (Eds.), Indigenous peoples' access to justice, including truth and reconciliation processes (pp. 255261). New York, NY: Institute for the Study of Human Rights, Columbia University.

Legacy of Hope Foundation. (n.d.). Where are the children? Healing the legacy of residential schools. Retrieved from http://wherearethechildren.ca/

Lincoln, K. R. (1983). Native American renaissance. Berkeley: University of California Press.

Liu, M., Moore, Z., Graham, L., \& Lee, S. (2003). A look at the research on computerbased technology in second language learning: A review of the literature from 1990-2000. Journal of Research on Technology in Education, 34(3), 250-273.

Mander, J. (1991). In the absence of the sacred: The failure of technology and the survival of the Indian Nations. San Francisco, CA: Sierra Club Books.

McHenry, T. (2002). Words as big as the screen: Native American languages and the Internet Language Learning \& Technology, 6(2), 102-115.

Morris, T. L. \& Meinrath, S. D. (2009). New media, technology and internet use in Indian country study. Flagstaff, AZ: Native Public Media.

Office of the Commissioner of Official Languages. (2018). Official languages in the provinces and territories. Retrieved from http://www.ocolclo.gc.ca/en/language_rights/provinces_territories

'Ōiwi TV (2009, October 12). Ulukau. Retrieved from http://oiwi.tv/aoo/ulukau'Ōiwi TV (2017). From Hawai' $i$, for the world. Retrieved from http://oiwi.tv/about/

Pimienta, D., Prado, D., \& Blanco, A. (2009). Twelve years of measuring linguistic diversity in the internet: Balance and perspectives. Paris, France: UNESCO. 
Retrieved from http://www.unesco.org/new/en/communication-and-

information/resources/publications-and-communication-

materials/publications/full-list/twelve-years-of-measuring-linguistic-diversity-inthe-internet-balance-and-perspectives/

Prensky, M. (2001). Digital natives, digital immigrants part 1. On the Horizon, 9(5), 1-6.

Rice, E., Haynes, E., Royce, P., \& Thompson, S. (2016). Social media and digital technology use among Indigenous young people in Australia: A literature review. International Journal for Equity in Health, (15). Retrieved from http://www.ncbi.nlm.nih.gov/pmc/articles/PMC4881203/

Riley, L. A., Nassersharif, B., \& Mullen, J. (1999). Assessment of technology infrastructure in Native communities (Economic Development Administration Report No. 99-07-13799). Washington, DC: U.S. Department of Commerce.

Ryan, K. (2016). Community-based materials: Using digital storytelling for teaching and learning Indigenous languages (Master's thesis). University of British Columbia. Retrieved from https://open.library.ubc.ca/cIRcle/collections/24/items/1.0300144

Scannell, K. (2012). Translating Facebook into endangered languages. Presentation at the 16th Foundation for Endangered Languages Conference on Language Endangerment in the 21st Century: Globalisation, Technology and New Media. Auckland, Aotearoa/New Zealand, 12-15 September 2012. Retrieved from http://borel.slu.edu/pub/fel12slides.pdf

Shiva, V. (1993). Monocultures of the mind: Perspectives on biodiversity and biotechnology. London, UK: Zed Books.

Silverstein, S. (2012, December). Bank of Hawaii adds Hawaiian language to ATM menu in Honolulu. Pacific Business News. Retrieved from http://www.bizjournals.com/pacific/blog/2012/12/bank-of-hawaii-adds-hawaiianlanguage.html

Slaughter, H. B. (1997). Functions of literacy in an Indigenous second language: Issues and insights from an ethnographic study of Hawaiian immersion. Paper presented at the meeting of the American Educational Research Association, Chicago, IL.

Smith, A. (2009). Indigenous peoples and boarding schools: A comparative study. New York, NY: United Nations. Retrieved from http://www.un.org/esa/socdev/unpfii/documents/E_C_19_2009_crp1.pdf

Smith, L. T. (1999). Decolonizing methodologies. London, UK: Zed Books.

State of Hawai'i (2016). Non-English speaking population in Hawaii. Honolulu, HI: State of Hawai 'i, Research and Economic Analysis Division Department of Business, Economic Development and Tourism. Retrieved from http://files.hawaii.gov/dbedt/economic/data_reports/Non_English_Speaking_Popu lation_in_Hawaii_April_2016.pdf

Te Huia, A. (2013). Whāia te iti kahurangi, ki te tuohu koe me he maunga teitei: Establishing psychological foundations for higher levels of Māori language proficiency. (Doctoral dissertation). Retrieved from http://researcharchive.vuw.ac.nz/xmlui/bitstream/handle/10063/3459/thesis.pdf?se quence $=2$

Truth and Reconciliation Canada. (2015). Honouring the truth, reconciling for the future: Summary of the final report of the Truth and Reconciliation Commission of Canada. Winnipeg: Truth and Reconciliation Commission of Canada. Retrieved 
from

http://www.trc.ca/websites/trcinstitution/File/2015/Honouring_the_Truth_Reconc iling_for_the_Future_July_23_2015.pdf

United Nations (n.d.). Indigenous peoples, Indigenous voices—fact sheet. New York, NY: United Nations. Retrieved from http://www.un.org/esa/socdev/unpfii/documents/5session_factsheet1.pdf

United Nations (2000). Report of the high-level panel of experts on information and communication technology. New York, NY: United Nations.

United Nations (2008). United Nations Declaration on the Rights of Indigenous Peoples. New York, NY: United Nations. Retrieved from https://www.un.org/development/desa/indigenouspeoples/declaration-on-therights-of-indigenous-peoples.html

United Nations Educational, Scientific and Cultural Organization (2009). Investing in cultural diversity and intercultural dialogue. Paris, France: UNESCO.

United Nations News (2007, September). United Nations adopts Declaration on Rights of Indigenous Peoples. Retrieved from

https://news.un.org/en/story/2007/09/231062-united-nations-adopts-declarationrights-indigenous-peoples

United States Congress (1990). Public law 101-477. Washington, DC: U.S. Government Printing Office. Retrieved from https://www.gpo.gov/fdsys/pkg/STATUTE104/pdf/STATUTE-104-Pg1152.pdf

United States Congress (1992). Public law 102-524. Washington, DC: U.S. Government Printing Office. Retrieved from https://www.gpo.gov/fdsys/pkg/STATUTE106/pdf/STATUTE-106-Pg3434.pdf

United States Congress (2006). Public Law 109-394. Retrieved from https://www.gpo.gov/fdsys/pkg/PLAW-109publ394/pdf/PLAW-109publ394.pdf

United States Congress, Office of Technology Assessment (1995). Telecommunications Technology and Native Americans: Opportunities and Challenges, OTA-ITC-621. Washington, DC: U.S. Government Printing Office.

United States Senate Committe on Indian Affairs (2000). Native American languages act amendments. Hearing before the committee on Indian Affairs United States Senate one hundred sixth congress second session on S. 2688 to amend the Native American Languages Act to provide for the support of Native American language survival schools. (S. Hrg. 106-648). Washington, DC: U.S. Government Printing Office. Retrieved from https://www.gpo.gov/fdsys/pkg/CHRG106shrg65921/pdf/CHRG-106shrg65921.pdf

University of Hawai'i. (2009, August 6). Google in Hawaiian [Press release]. Retrieved from https://hilo.hawaii.edu/news/press/release/842

University of Hawai'i Hilo. (2017). Hale Kuamo`o Hawaiian language center. Retrieved from https://hilo.hawaii.edu/catalog/hale-kuamoo-center-for-hawaiian-language

Villa, D. J. (2002). Integrating technology into minority language preservation and teaching efforts: An inside job. Language Learning \& Technology, 6(2), 92-101.

Vlugter, P., Knott, A., McDonald, J., \& Hall, C. (2009). Dialogue-based CALL: A case study on teaching pronouns. Computer Assisted Language Learning, 22(2), 115131, DOI: $10.1080 / 09588220902778260$

Ward, M. (2004). The additional uses of CALL in the endangered language context. 
ReCALL, 16(2), 345-359.

Ward, M. \& Genabith, J. (2003). CALL for endangered languages: Challenges and rewards. Computer Assisted Language Learning, 16(2-3), 233-258.

Warner, S. (1999). Kuleana: The right, responsibility, and authority of Indigenous peoples to speak and make decisions for themselves in language and cultural revitalization. Anthropology \& Education Quarterly, 30(1), 68-93.

Warschauer, M. (1998). Technology and Indigenous language revitalization: analyzing the experience of Hawai' $i$. Canadian Modern Language Review, 55(1), 139-159.

Warschauer, M. \& Donaghy, K. (1997). Leokī: A powerful voice of Hawaiian language revitalization. Computer Assisted Language Learning, 10(4), 349-361.

Wilson, W. H. (1998). The sociopolitical context of establishing Hawaiian-medium education. Language, Culture and Curriculum, 11(3), 325-338.

Wyman, L. T. (2012). Youth culture, language endangerment and linguistic survivance. Bristol, UK: Multilingual Matters.

Wyman, L., Galla, C. K., \& Jimenez-Quispe, L. (2016). Indigenous youth language resources, educational sovereignty, and praxis-oriented research: Connecting a new body of language planning research to the work of Richard Ruiz. In N. Hornberger (Ed.), Honoring Richard Ruiz and his work on language planning and bilingual education (pp. 395-429). Bristol: Multilingual Matters.

Wyman, L. T., McCarty, T. L., \& Nicholas, S. E. (Eds.). (2014). Indigenous youth and multilingualism: Language identity, ideology, and practice in dynamic cultural worlds. New York, NY: Routledge.

Zepeda, O. (2008). Where clouds are formed. Tucson, AZ: University of Arizona Press. 